\title{
AN ANALYTICAL MODELLING APPROACH TO OPTIMIZE SAFETY STOCK OF WINERY SUPPLY CHAINS (WSC)
}

\author{
D C L De Zoysa ${ }^{1}$ and Thashika D Rupasinghe ${ }^{2}$ \\ * Department of Industrial Management, University of Kelaniya, Sri Lanka
}

\begin{abstract}
Winery Supply Chains (WSC) are more cash sensitive as a considerable portion of inventory is kept and financed throughout the WSC due to the long production process, distances from suppliers/markets and the importance of having the correct finished goods for orders. Hence, Inventory Optimization (IO) is one of the most critical areas in a WSC. This paper is framed on introducing a Genetic Algorithm (GA) incorporating a mathematical model that integrates selected external and internal characteristics of WSCs together with demand uncertainties specific to WSC, developed by the authors to optimize the most critical type of inventory, the safety stock level of WSC. This paper further compares three main types of inventory policies, the continuous review, the periodic review policy and a hybrid of both policies, which analyze their impact on selected Key Performance Indicators (KPI). The developed simulation models incorporating the comparison, integrates demand specific for wine products to a distributor in a Winery Supply Chain. This paper fulfils a larger knowledge gap in the arena of IO for WSC and presents the foundation for larger research projects in IO for WSC. Thus, the generic safety stock model would enable the WSCs achieve higher performance leading to competitive advantage.
\end{abstract}

Keywords: Demand Uncertainties, Genetic Algorithm, Safety Stock, Simulation, Winery Supply Chains

\section{Introduction}

The major cause for the existence of inventory in a supply chain (SC) is the mismatch of demand and supply. The overstock of inventory is not suitable due to the higher investment on it and the costs associated. The non-availability or the shortage of inventory would result in disturbance of the production process as well as poor customer satisfaction levels. Though inventory has been invented in to SCs to tackle uncertainty, existence of tradeoffs has brought out the attention of the corporates to find the appropriate inventory policy that specifies 1) when an order for additional items should be placed and 2) how many items should be ordered each time [Heizer, J. \& Render, B., 1999] and [Lipman, B., 1975]. Under the assumption that the manufacturing world is deterministic and is with adequate capacity, only pipeline stocks and cycle stocks would only be needed that can be easily predicted. But today, it is not the case. The most significant is the decision on the inventory more than the pipeline and cycle stock. According to [Graves, 1988], safety stock is the "excess" inventories held beyond the minimum inventory level that would be possible in a deterministic and incapacitated world. This is needed in the manufacturing systems due to the uncertainties depicted above. Thus, this study focuses on the "inventory that is maintained explicitly to protect the organization just in case one or more of these problems occur is called buffer inventory or safety stock" [Chapman, 2006]. In simple terms, safety stock is mainly the inventory kept in to minimize the stock outs. This paper introduces an efficient GA to solve the safety stock optimization mathematical model under demand uncertainties for WSC developed by the authors in which internal \& external characteristics specific for WSC have been integrated, such as storage factors, wine constituents, inflation and tax rates [De Zoysa, D.L. and Rupasinghe, T.D., 2016]. This GA development is followed by a Design of Experiment (DoE) to tune

Corresponding Authors: ${ }^{1}$ chatrulzdzs@ gmail.com, ${ }^{2}$ thashika@kln.ac.lk 
the algorithm that enables the users undertake better parameter fixing to receive near optimal values for the level of safety stock that should be maintained. Further, this study compares selected inventory policies out of the many different types of inventory policies that would enable corporates identify the most appropriate answers for the two questions mentioned above. However, most of these models are restricted to certain restrictions such as constant demand. In this study, the three simulated models for each of the selected three inventory policies would integrate variation or uncertainty in demand for a distributor in a highly uncertain and cash sensitive SC, the WSC. The modelling has been performed using the Arena simulation package.

\section{Methodology}

This study is performed in order to fill the knowledge gap pertaining in the area of safety stock optimization for winery supply chains. An easily solvable safety stock optimization model would enable the winery businesses to reduce their cost of inventory and increase customer service levels by ensuring that the optimal amount of stock is kept within the supply chain to avoid stock out or shortages.

After a review of literature, a mathematical model for safety stock optimization is developed integrating selected intrinsic and extrinsic characteristics of the wine products and the WSC [De Zoysa, D.L. and Rupasinghe, T.D., 2016]. Then meta-heuristic algorithms using GA has been developed to solve the mathematical model with computational efficiency. Then the developed GA has been tuned performing a Design of Experiment (DoE). Further, the study has been expanded in to modelling selected inventory policies for WSC to assess the effect of them for the selected inventory policies, bringing out the importance of maintaining the optimum level of safety stock. The Table 1 provides a summary of the review of literature on safety stocks [De Zoysa, D.L. and Rupasinghe, T.D., 2016].
Table 1 Summary of the Literature Review

\begin{tabular}{|c|c|}
\hline References & Summary \\
\hline $\begin{array}{l}\text { [Funaki, K., } \\
\text { 2012] }\end{array}$ & $\begin{array}{l}\text { Application Area: Optimization } \\
\text { model for safety stock placement in a } \\
\text { SC network for an assembly SC. } \\
\text { Objective: Minimizing the total cost } \\
\text { including the processing and transit } \\
\text { cost with stock holding cost. }\end{array}$ \\
\hline $\begin{array}{l}\text { [Lesnaia, E. } \\
\text { et al., 2004] }\end{array}$ & $\begin{array}{l}\text { Application Area: Placement of } \\
\text { safety stock in a general network SC. } \\
\text { Objective: Maintaining the required } \\
\text { service level. }\end{array}$ \\
\hline $\begin{array}{l}\text { [Graves, S. } \\
\text { C., \& } \\
\text { Willems, S. } \\
\text { P., 2003] }\end{array}$ & $\begin{array}{l}\text { Application Area: Placement of } \\
\text { safety stocks in a SC. } \\
\text { Objective: Minimize the total supply } \\
\text { chain cost. }\end{array}$ \\
\hline $\begin{array}{l}\text { [Boulaksil, } \\
\text { Y. et al., } \\
\text { 2009] }\end{array}$ & $\begin{array}{l}\text { Application Area: Determination of } \\
\text { safety stocks in multi-item, multi- } \\
\text { stage inventory systems that face } \\
\text { demand uncertainties considering } \\
\text { constraints such as batch sizes, } \\
\text { capacity and material constraints. } \\
\text { Objective: Minimize the total supply } \\
\text { chain cost. }\end{array}$ \\
\hline $\begin{array}{l}\text { [Simchi- } \\
\text { Levi, D., \& } \\
\text { Zhao, Y., } \\
\text { 2005] }\end{array}$ & $\begin{array}{c}\text { Application Area: Numerical and } \\
\text { analytical insights have been } \\
\text { developed in the recursive equations } \\
\text { with respect to safety stock } \\
\text { positioning with stochastic lead } \\
\text { times. } \\
\text { Objective: Minimize the total supply } \\
\text { chain cost. }\end{array}$ \\
\hline $\begin{array}{c}\text { [Heath, D., \& } \\
\text { Jackson, P., } \\
\text { 1994] }\end{array}$ & $\begin{array}{l}\text { Application Area: A simulation } \\
\text { model is developed to analyze the } \\
\text { safety stock levels for a } \\
\text { multiproduct/plant production system } \\
\text { with stochastic demand. } \\
\text { Objective: Find the economic safety } \\
\text { stock factor. }\end{array}$ \\
\hline $\begin{array}{l}\text { [Inderfurth, } \\
\quad \text { K., \& } \\
\text { Vogelgesang, } \\
\text { S., 2013] }\end{array}$ & $\begin{array}{l}\text { Application Area: analyze the safety } \\
\text { stock levels for a multiproduct/plant } \\
\text { production system with stochastic } \\
\text { demand. } \\
\text { Objective: Minimize the logistic cost. }\end{array}$ \\
\hline
\end{tabular}

\section{Results}

\section{Development of a Safety Stock Optimizing Genetic Algorithm}

A Genetic Algorithm is developed to optimize the safety stock level of WSCs incorporating the 
mathematical model of optimizing the safety stock level [De Zoysa, D.L. and Rupasinghe, T.D., 2016]. The objective of this model (10), is to find the closeto-optimal values for $\mathrm{n}, \mathrm{K}$ and $\mathrm{SS}$ while minimizing the total variable cost of inventory (TC), where $i=1$, $\ldots \mathrm{n}[\mathrm{i}=1$; product 1$]$ and at the same time minimizing the safety stock level for each product in the portfolio, maintaining the required capacity constraints (11), where Kapi = capacity of product $i$ and Kapmaxi = maximum capacity of product $\mathrm{i}$ and service level constraints (12), where SLi > 0 . Equations, (13) and (14) depict the non-negativity constraints.

$$
\begin{aligned}
& \operatorname{Min}\left[\sum_{\mathrm{i}=1}^{\mathrm{n}}\left\{\mathrm{TC}_{\mathrm{i}}(\mathrm{n}, \mathrm{K}), \mathrm{SS}_{\mathrm{i}}\right\}\right] \\
& \mathrm{Kap}_{\mathrm{i}} \leq \text { Kapmax }_{\mathrm{i}} \\
& \mathrm{SL}_{\mathrm{i}} \geq \text { SLexpected }_{\mathrm{i}}
\end{aligned}
$$

$$
\mathrm{SS}_{\mathrm{i}} \geq 0
$$

$$
\mathrm{i}, \mathrm{j} \geq 0
$$

Genetic algorithm is a population based metaheuristic technique. It starts with the current population. Selection is applied to the current population to create an intermediate population. Then crossover and mutation are applied to the intermediate population to create the next population. The process of going from the current population to the next population constitutes one generation in the execution of a genetic algorithm. The genetic algorithm is developed using java. Since this is the first instance of using genetic algorithms on the problem of safety stock optimization under high demand uncertainties, specific for WSCs there are no direct implementations to be found which can be compared to our implementation. The pseudocode for the developed genetic algorithm is depicted below.

\section{Input}

Read array of demand to be served for each quarter $\{P 1, P 2, P 3, P 4, P 5, P 6\}$

Population size $(p)$

Number of generations $(G)$

//Initialization
Create a chromosome with a random set I gene for each product (safety stock, tax rate, Inflation1,

Inflation2, aging factor)\}

Check for capacity constraints

Check for demand constraints

Check for no shortages

Do this for $p$ times to create a population

Get the best chromosome from the population

Save as the elite

Initial TC = total cost (TC) of the fittest chromosome in first population

//Genetic Algorithm

//Run for $n$ times

Loopl \{

//Run for p times

Loop2 \{

//Tournament selection

Select a random set of tours from the population

Get the fittest and return

//Crossover

Parent 1 = tournament selection()

Parent2 = tournament selection()

Child $=$ Crossover $($ Parent 1, Parent 2$)$

//Mutation

Swap random two columns in the child

\} endLoop2

//New population is created

Get the fittest

Replace previous elite if fittest is better than elite

\} endLoop 1

Get the elite

Final TC $=$ TC of elite

Reduction of TC $=($ initial TC-final TC $)$

Print "Reduction of TC"

\section{Test Case Formulation}

A hypothetical test case for a set of six products, has been developed to demonstrate how this model can be used. Assume that the fixed period in which the standard deviation of the demand that tends to be small enough for the EOQ model to be used under stochastic demand is 20 quarters and 4 orders are placed during the fixed period. The external purchase cost per unit, the internal ordering cost, internal and external inflation rates, internal and external holding costs and shortage cost per unit item per unit time, service level and capacity for the product, total lead time, time increment used in calculating the standard deviation for demand needs to be identified for each product in the portfolio. Most importantly, the 
relationship of wine constituents and storage factors for the amelioration of wine needs to be identified by analyzing industry data. In the hypothetical test case, it is being assumed that the distributor holds the inventory in an internal warehouse, so that only the internal inflation rates would be applicable and the lead time is deterministic. The same discount rate $(11 \%)$ and the same replenishment cycle and reorder quantity is applied for each of the six products in the portfolio. The Table 2 depicts the hypothetical cost values for each of the six products in the portfolio in developing the hypothetical test case that is incorporated in developing the GA.

Table 2 Cost Components used for Test Case Formulation

\begin{tabular}{ccccccc}
\hline Cost & \multicolumn{6}{c}{ Product Portfolio } \\
\cline { 2 - 7 }$\$$ & P1 & P2 & P3 & P4 & P5 & P6 \\
\hline $\mathrm{c}_{11}$ & 40.5 & 45.0 & 55.0 & 42.5 & 43.0 & 55.0 \\
\hline
\end{tabular}

\begin{tabular}{ccccccc}
\hline$c_{21}$ & 35.0 & 35.0 & 38.0 & 48.0 & 40.0 & 48.0 \\
\hline $\mathrm{A}$ & 30.0 & 35.0 & 40.0 & 50.0 & 45.0 & 55.0 \\
\hline $\mathrm{p}$ & 35.0 & 55.0 & 53.0 & 43.0 & 58.0 & 60.0 \\
\hline
\end{tabular}

\section{Results of the Design of Experiments (DoE)}

To analyze the performance of GA, the experiment has been designed as follows in the Table 3 .

Table 3 DoE Parameters

\begin{tabular}{ccc}
\hline Crossover Rates & 0.3 & 0.8 \\
\hline Replications & $\begin{array}{c}\text { 10 per one crossover rate, per } \\
\text { one population size, per one set } \\
\text { of generations }\end{array}$ \\
\hline No. in Population & \multicolumn{2}{c}{50} \\
\hline No.of Generations & 100 & 1000 \\
\hline & &
\end{tabular}

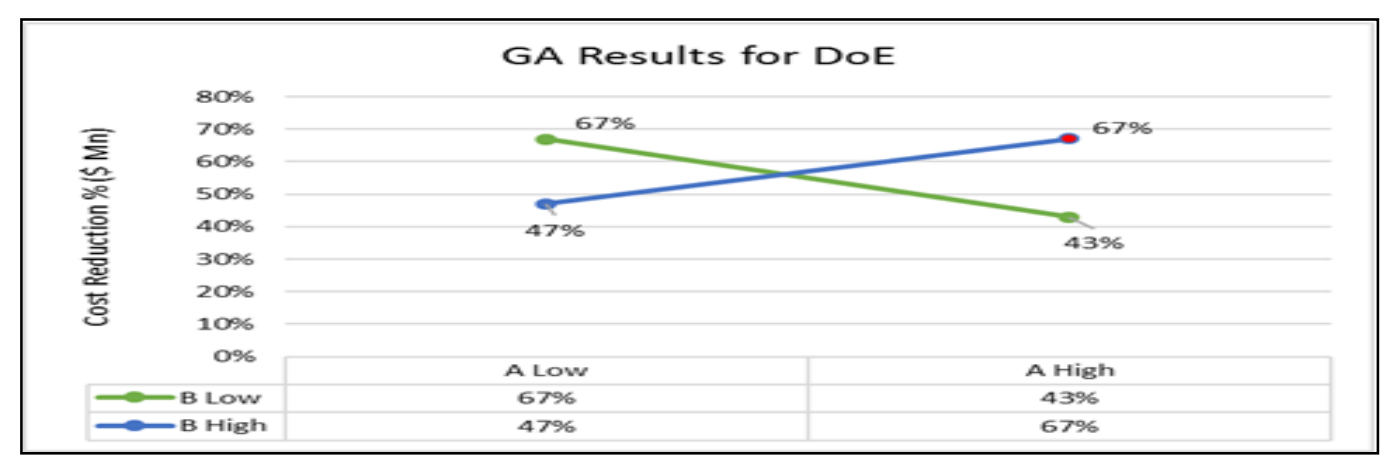

Figure 1 Results of the Genetic Algorithm for DoE

Note that these crossover rates, size of the population and number of generations are the most widely used values found on the literature. The outcome of GA is cost reduction compared to initial total cost (TC) of the elite chromosome for the product portfolio. The data points for each cross over rates can be seen in the Table 4 below.

Table 4 GA Results for each Crossover Rates

\begin{tabular}{cc}
\hline $\begin{array}{c}\text { Crossover Rate }=0.3 \\
(\$ \mathrm{Mn})\end{array}$ & $\begin{array}{c}\text { Crossover Rate }=0.8 \\
(\$ \mathrm{Mn})\end{array}$ \\
\hline 6.69 & 0.00 \\
\hline 23.99 & 28.67 \\
\hline 11.31 & 10.80 \\
\hline
\end{tabular}

\begin{tabular}{cc}
\hline 12.44 & 17.17 \\
\hline 11.98 & 3.20 \\
\hline 0.00 & 4.50 \\
\hline 14.96 & 8.13 \\
\hline 11.32 & 0.00 \\
\hline 8.40 & 9.01 \\
\hline 19.03 & 0.00 \\
\hline 12.67 & 0.32 \\
\hline 7.82 & 16.43 \\
\hline 5.82 & 7.73 \\
\hline 5.70 & 9.44 \\
\hline 15.64 & 8.30 \\
\hline 12.96 & 31.83 \\
\hline
\end{tabular}




\begin{tabular}{cc}
\hline 1.48 & 16.40 \\
\hline 9.52 & 18.55 \\
\hline 17.75 & 5.17 \\
\hline 16.30 & 5.98 \\
\hline
\end{tabular}

The below Table 4 depicts the full factorial design for the DoE for each two factors (size of generations and crossover rate) with two levels (High and Low).

Table 5 Full Factorial Design of the Experiments

\begin{tabular}{cccc}
\hline Factor Name & $\begin{array}{c}\text { Factor } \\
\text { Name }\end{array}$ & $\begin{array}{c}\text { Low } \\
\text { Setting }\end{array}$ & $\begin{array}{c}\text { High } \\
\text { Setting }\end{array}$ \\
\hline Size of Generations & A & 100 & 1000 \\
\hline Crossover Rates & B & 0.3 & 0.8 \\
\hline
\end{tabular}

The following Table 6, depicts the results of the GA for each parameter experiment.

Table 6 Results of the Genetic Algorithm

\begin{tabular}{ccccc}
\hline $\begin{array}{c}\text { Selected } \\
\text { Parameter }\end{array}$ & \multicolumn{4}{c}{$\begin{array}{c}\text { Values for the Parameter of the } \\
\text { GA }\end{array}$} \\
\hline $\begin{array}{c}\text { Size of the } \\
\text { Population }\end{array}$ & \multicolumn{4}{c}{50} \\
\hline $\begin{array}{c}\text { Size of } \\
\text { Generations }\end{array}$ & \multicolumn{2}{c}{100} & & \multicolumn{2}{c}{1000} \\
\hline Crossover Rates & 0.3 & 0.8 & 0.3 & 0.8 \\
\hline $\begin{array}{c}\text { Average TC } \\
\text { Reduction \% }\end{array}$ & $67 \%$ & $47 \%$ & $43 \%$ & $67 \%$ \\
\hline
\end{tabular}

According to the above Table 5 and Figure 1, the highest average cost reduction is arrived at when the size of the generation is 1000 and the crossover rate is 0.8 for the population size of 100.After tuning the GA using the design of experiments, the tuned GA is run to get the results. The following Table 7 below depicts the results of the tuned GA.

Table 7 Results of the tuned Genetic Algorithm

\begin{tabular}{cccccccc}
\hline $\begin{array}{c}\text { Produc } \\
\mathrm{t}\end{array}$ & $\begin{array}{c}\mathrm{P} \\
\text { Averag }\end{array}$ & P2 & P3 & P4 & P5 & P6 \\
$\begin{array}{c}\mathrm{e} \\
\begin{array}{c}\text { Safety } \\
\text { Stock }\end{array}\end{array}$ & $\begin{array}{c}34.0 \\
5\end{array}$ & $\begin{array}{c}9 . \\
6\end{array}$ & 43.3 & $\begin{array}{c}16 . \\
85\end{array}$ & 26.5 & 34.1 \\
\cline { 1 - 5 } $\begin{array}{c}\text { Averag } \\
\mathrm{e}\end{array}$ & $\begin{array}{c}130 . \\
6\end{array}$ & $\begin{array}{c}13 \\
6\end{array}$ & $\begin{array}{c}139 . \\
25\end{array}$ & $\begin{array}{c}131 \\
.4\end{array}$ & $\begin{array}{c}130 . \\
45\end{array}$ & $\begin{array}{c}129 . \\
05\end{array}$ \\
\hline
\end{tabular}

Invent

ory

$\begin{array}{ccccccc}\text { Safety } & & & & & & \\ \text { Stock } & 26.1 & 7 . & 31.1 & 12 . & 20.3 & 26.4 \\ \% & & 1 & & 8 & & \end{array}$

\section{Simulation Models}

This The simulation software, the student version of Arena is used to construct the inventory management system of a Distribution Centre (DC) in a WSC. In each policy, the DC would place orders evaluating its inventory level only. The simulation would be run for 365 days (a year). The general operations for the inventory models would be as follows.

1.The DC receives the orders for wine cases from retailers, weekly, each case of $12,750 \mathrm{ml}$ bottles.

2.The DC receives deliveries from the Filler (bottler) in a WSC that was ordered L (constant lead time) periods ago.

3.The DC fulfills its customer orders (plus backorders if any) with the inventory on hand and the safety stock available. If there are not enough inventories, the unfulfilled quantity will be backordered. Note that the retailers will wait until the DC can fulfill the order.

4.In the continuous review, the DC monitors the inventory on hand each time an order arrives and backordering and follows a $(r, Q)$ policy.

5.In the periodic review, the inventory on hand is reviewed in a fixed time interval $\mathrm{T}$ and follows $(\mathrm{s}, \mathrm{S})$ policy.

6.In the hybrid model both ( $\mathrm{r}, \mathrm{Q})$ and $(\mathrm{s}, \mathrm{S})$ is followed. The safety stock is continuously reviewed and updated.

Following figures would depict the Arena models developed for each inventory policy. Figure 2 depicts the continuous review model where replenishment order is placed when the inventory on hand is up to or below the reorder point $r$ and a fixed quantity of $Q$ is ordered in each replenishment order. During the lead time for the replenishment, the demand is satisfied using safety stocks or else are queued in backorders. 


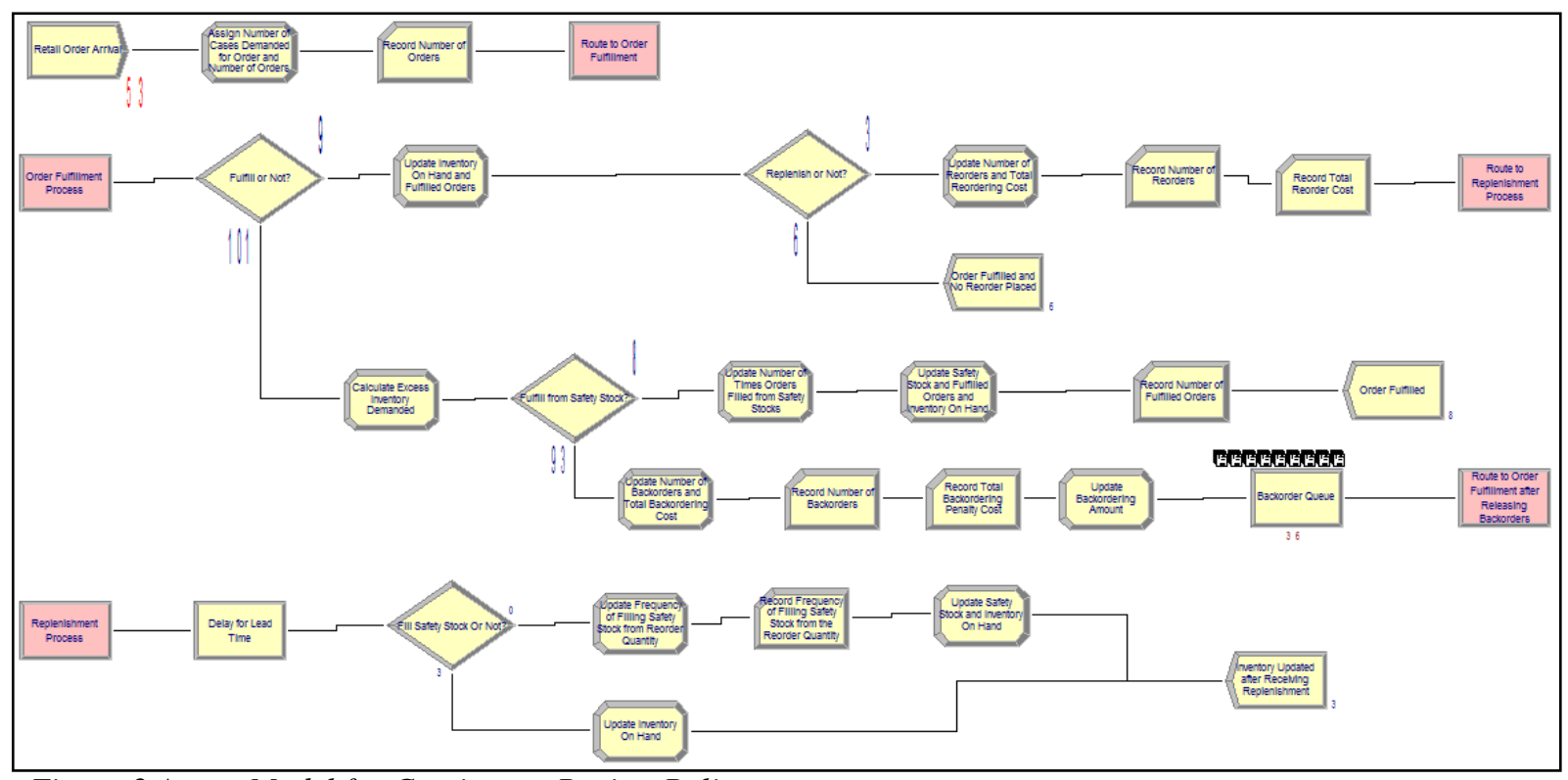

Figure 2 Arena Model for Continuous Review Policy

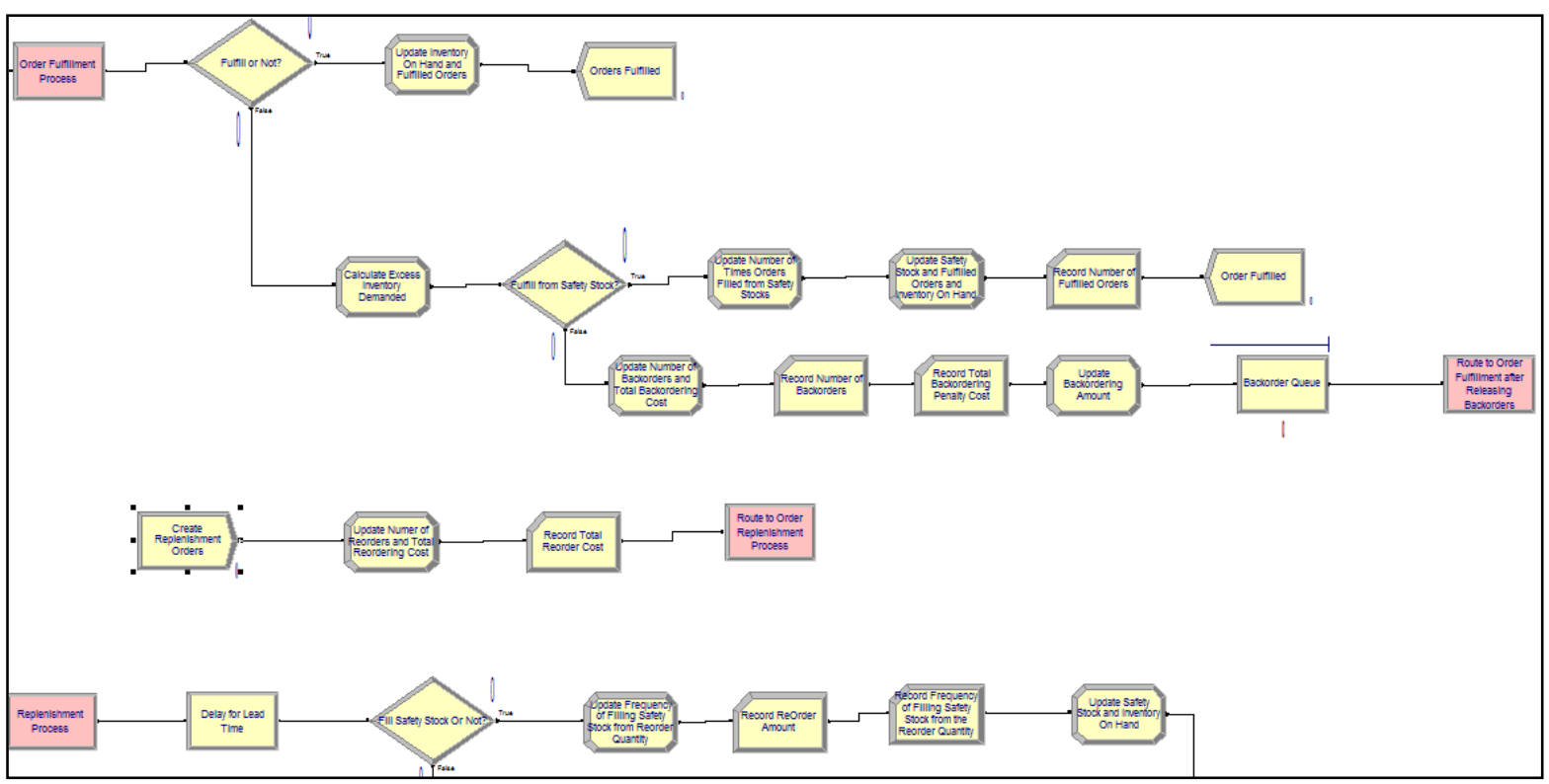

Figure 3 Arena Model for Periodic Review Policy

As soon as the replenishment order arrives, safety stock is filled up to the fixed level and the backorders are satisfied. Figure 3 Depicts the periodic review model where a replenishment order is placed every $\mathrm{T}$ time period, with the quantity to maintain the target inventory level. During that time, shortage inventory would be taken from the safety stock or else are queued in backorders.
The hybrid model that incorporates characteristics of both the previous models depicted in Figure 4 reviews the inventory level during a fixed time interval $\mathrm{T}$ greater than the normal periodic time but a reorder point for the safety stock level is fixed and each time the safety stock falls below that, a replenishment order is placed. Following Table 8 depicts the initial values for the variables in each inventory model. 


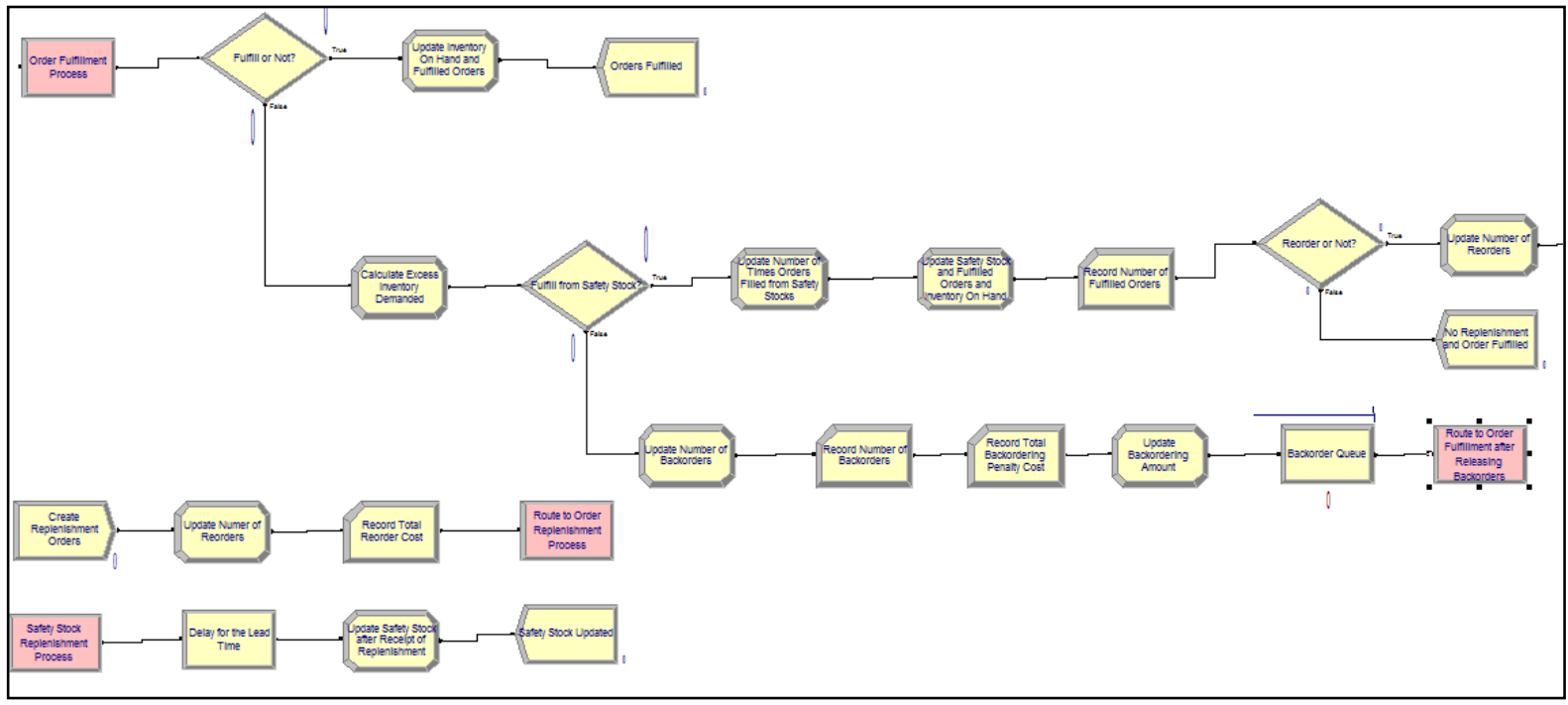

\section{Data Generation for Simulation Models}

Demand for wine is generated using the instrumental variable (IV) regression formula (1), introduced by [Cuellar, S. S., \& Huffman, R., 2009], where the wine

Figure 4 Arena Model for the Hybrid Model

demand vary for price and income changes for the period. Random data are generated for the price and income using the Research Randomizer, a random number generator.

Table 8 Initial values for model variables

\begin{tabular}{cc}
\hline Variables & Value \\
\hline Inventory on Hand & 10000 \\
\hline Reorder Point & 5000 \\
\hline Fixed Safety Stock & 3000 \\
\hline Reorder Quantity & 1000 \\
\hline Target Inventory Level & 10000 \\
\hline Lead Time & 5 days \\
\hline $\begin{array}{c}\text { Review Time Interval (Periodic } \\
\text { Review) }\end{array}$ & 30 days \\
\hline Review Time Interval (Hybrid) & 60 days \\
\hline Reorder Point for Safety Stock & 1000 \\
\hline
\end{tabular}

Cases $_{\mathrm{jt}}=\beta_{0}+\beta_{1}$ Price $_{\mathrm{jt}}+\beta_{2}$ Income $_{\mathrm{jt}}$

where; $\mathrm{j}=1,2$, $\mathrm{n}$ weeks of year $\mathrm{t}=1,2, \mathrm{n}$

Weekly demand for wine cases is taken as a fit for the normal distribution of a mean of 1430 with a $95 \%$ confidence level. To depict the effect of the unstable and variable demand, to demand distributions with the same mean demand but with two different coefficients of variance $(\mathrm{CV})$ are considered.

\section{Performance Measures}

Each modelled inventory policy is measured for its performance against the below selected KPIs in terms of inventory depicted in Table 9.

\section{Table 9 Key Performance Indicators}

\begin{tabular}{|c|c|}
\hline KPIs & Calculations \\
\hline Fill Rate & $\frac{\text { Number of Fulfilled Orders }}{\text { Number of Orders Received }} \times 100 \%$ \\
\hline $\begin{array}{l}\text { Avg Reordering } \\
\text { Cost per Week }\end{array}$ & $\frac{\text { Total Reordering Cost }}{\text { Number of Weels for the Simulation Rur }}$ \\
\hline $\begin{array}{c}\text { Avg } \\
\text { Backordering } \\
\text { Penalty Cost per } \\
\text { Week }\end{array}$ & $\frac{\text { Total Backordering Cost }}{\text { Number of Weelss for the Simulation Rur }}$ \\
\hline $\begin{array}{l}\text { Number of Stock } \\
\text { Outs per Week }\end{array}$ & $\frac{\text { TotalNumber of Backorders }}{\text { Number of Weeks for the Simulation Rur }}$ \\
\hline \multicolumn{2}{|c|}{$\begin{array}{l}\text { As depicted in Table } 9 \text {, Fill Rate and the Number of } \\
\text { Stock Outs per Week would show the level of } \\
\text { customer satisfaction while the other cost based KPIs } \\
\text { show the cost hidden in inventory decisions for each } \\
\text { inventory policy. The backordering penalty cost per } \\
\text { order is taken as } \$ 10000 \text { and the reordering cost per } \\
\text { reorder is taken as } \$ 20000 \text { for simulation purposes. } \\
\text { In each simulation run for each inventory policy } \\
\text { model for the two CVs of wine demand, another } \\
\text { specific variable is measured, the number of times } \\
\text { orders are fulfilled the existing safety stock available } \\
\text { in the DC. }\end{array}$} \\
\hline
\end{tabular}




\section{Results of the Simulation Study}

For each of the models the wine demand is of a 1430 mean per week and the replication length is 365 days. The two CVs for the two types of demand variability, high and low are 0.98 and 0.07 respectively. Results obtained from the simulation runs for each type of variability in demand for each three types of inventory policy models are depicted in Table 10, Table 11 and Table 12 below.

Table 10 Results for Continuous Review Model

\begin{tabular}{ccc}
\hline KPIs and Variables & $\mathrm{CV}=0.07$ & $\mathrm{CV}=0.98$ \\
\hline $\begin{array}{c}\text { Avg Backorder Cost } \\
\text { per Week }\end{array}$ & 2547.95 & 2547.95 \\
\hline $\begin{array}{c}\text { Avg Reorder Cost per } \\
\text { Week }\end{array}$ & 164.38 & 164.38 \\
\hline Fill rate & $28.3 \%$ & $32.1 \%$ \\
\hline $\begin{array}{c}\text { Number of Stock Outs } \\
\text { per Week }\end{array}$ & 1.79 & 1.79 \\
\hline $\begin{array}{c}\text { Number of Times } \\
\text { Orders Fulfilled from } \\
\text { Safety Stock }\end{array}$ & 6 & 8 \\
\hline
\end{tabular}

According to the results for the continuous review model in Table 10, it is seen that there is no effect on the backorders and the reorders against the demand variation. But the under the high demand variations, the number of times orders are fulfilled from the safety stocks are high depicting the importance of availability of safety stocks in maintaining or achieving higher fill rates during high demand uncertainty.

Table 11 Results for the Periodic Review Model

\begin{tabular}{ccc}
\hline KPIs and Variables & $\mathrm{CV}=0.07$ & $\mathrm{CV}=0.98$ \\
\hline $\begin{array}{c}\text { Avg Backorder Cost } \\
\text { per Week }\end{array}$ & 27.40 & 54.79 \\
\hline $\begin{array}{c}\text { Avg Reorder Cost } \\
\text { per Week }\end{array}$ & 657.53 & 657.53 \\
\hline Fill rate & $100.0 \%$ & $100.0 \%$ \\
\hline $\begin{array}{c}\text { Number of Stock } \\
\text { Outs per Week }\end{array}$ & 0.02 & 0.04 \\
\hline $\begin{array}{c}\text { Number of Times } \\
\text { Orders Fulfilled from } \\
\text { Safety Stock }\end{array}$ & 2 & 4 \\
\hline
\end{tabular}

Table 12 Results for the Hybrid Model

\begin{tabular}{ccc}
\hline KPIs and Variables & $\mathrm{CV}=0.07$ & $\mathrm{CV}=0.98$ \\
\hline $\begin{array}{c}\text { Avg Backorder Cost } \\
\text { per Week }\end{array}$ & 0.00 & 82.19 \\
\hline
\end{tabular}

\begin{tabular}{ccc}
\hline $\begin{array}{c}\text { Avg Reorder Cost } \\
\text { per Week }\end{array}$ & 328.77 & 328.77 \\
\hline Fill rate & $100.0 \%$ & $100.0 \%$ \\
\hline $\begin{array}{c}\text { Number of Stock } \\
\text { Outs per Week }\end{array}$ & 0 & 0.06 \\
\hline $\begin{array}{c}\text { Number of Times } \\
\text { Orders Fulfilled from } \\
\text { Safety Stock }\end{array}$ & 12 & 20 \\
\hline
\end{tabular}

According to the results in Table 11 for the periodic review, it is seen under high demand variability, backorders have increased resulting in increase of backordering cost and the stock outs per week. It is also seen that the increment on the number of times orders are fulfilled from safety stocks have increased and that is the reason for maintaining higher fill rates under demand uncertainty. Increase in the number of stock outs have increased in high demand variation in the hybrid model as well and it is seen that the increment of the number of times the orders are filled using safety stocks have resulted in maintaining higher fill rates. This may be due to the continuous replenishment of the safety stock level in the hybrid model that has enabled fulfilling orders without stock outs despite the fact that the review period is higher than the periodic review model. According to the below Table 13, the inventory policy type that gives the favorable values for the two variables are depicted. It is seen that during the high demand variability, the hybrid model has been able to fulfill orders from the safety stock, while the periodic review has been able to reduce number of stock outs per week, both resulting in higher fill rate.

Table 13 Analysis of the Variables

\begin{tabular}{ccc}
\hline Variables & $\begin{array}{c}\text { Low Demand } \\
\text { Variability }\end{array}$ & $\begin{array}{c}\text { High Demand } \\
\text { Variability }\end{array}$ \\
\hline $\begin{array}{c}\text { Number of Stock } \\
\text { Outs per Week }\end{array}$ & Hybrid & Periodic \\
\hline $\begin{array}{c}\text { Number of } \\
\text { Times Orders }\end{array}$ & Hybrid & Hybrid \\
$\begin{array}{c}\text { Fulfilled from } \\
\text { Safety Stock }\end{array}$ & & \\
\hline
\end{tabular}

\section{Conclusion}

This paper shows the effect of the different inventory policies for the performance of WSCs, both in low and high demand variability through simulation. For the better management of the cost and the service level tradeoffs of inventory, the most appropriate 
inventory policies should be adopted. It is seen that, in demand uncertainties for WSCs, integration of both the continuous and periodic review policies could result in policies that present better performance than merely adopting one policy alone.

It is also concluded that the availability of safety stock is of higher importance under high demand uncertainties in WSCs to achieve a higher customer satisfaction level or fill rate. As the safety stock is not available for free, optimization of safety stock for WSCs under high demand uncertainties is highly important.

Further, this study while filling a vast knowledge gap for WSCs, enables the WSCs achieve one of the key objectives, reducing the cost of logistics activities by optimizing the level of the excess stock that is needed to be held within the supply chain under high demand uncertainties, introducing a computationally efficient GA with defined best parameters to solve the mathematical model for a product portfolio and most eminently, this study is the first instance of introducing a tuned GA focusing specifically on optimizing the safety stock level for a WSC. The tuned GA proposes that the average level of the safety stock to be maintained is about $20 \%$ of the average inventory for the developed test case. Thus the performance of WSCs is improved, leading to competitive advantage.

One suggestion for future research would be to integrate supplier and process uncertainties as well for this model as this study is only taking demand uncertainty in to consideration. Another way to enhance this study is to integrate more intrinsic and extrinsic characteristics of WSCs apart from the ones considered in this model.

\section{References}

Boulaksil, Y. et al., (2009). Setting safety stocks in multi-stage inventory systems under rolling horizon mathematical programming models. Supply Chain
Planning: Quantitative Decision Support and Advanced Planning Solutions, 199-218.

Chapman, S.N. (2006). Fundamentals of Production Planning and Control. Pearson/Prentice Hall, Upper Saddle River.

Cuellar, S. S., \& Huffman, R. (2009). Estimating the Demand for Wine Using Instrumental Variable Techniques *, 3(2), 1-13.

De Zoysa, D.L. and Rupasinghe, T.D., (2016). Development of a safety stock optimization model with high demand uncertainties for Winery Supply Chains (WSCs). In Manufacturing \& Industrial Engineering Symposium (MIES) (pp. 1-5). IEEE.

Funaki, K., (2012). Strategic safety stock placement in supply chain design with due-date based demand. International Journal of Production Economics, 135(1), 4-13.

Graves, S. C., \& Willems, S. P., (2003). Supply Chain Design: Safety Stock Placement and Supply Chain Configuration. Handbooks in Operations Research and Management Science.

Heath, D., \& Jackson, P., (1994). Modeling the evolution of demand forecasts ITH application to safety stock analysis in production/distribution systems. IIE Transactions.

Heizer, J. \& Render, B. (1999). Operations management. Upper Saddle River, N.J., Prentice Hall.

Inderfurth, K., \& Vogelgesang, S., (2013). Concepts for safety stock determination under stochastic demand and different types of random production yield. European Journal of Operational Research, 224(2), 293-301.

Lesnaia, E. et al., (2004). Optimizing Safety Stock Placement in General Network Supply Chains. Proceedings of Singapore-MIT Alliance Annual Symposium Conference, 214.

Lipman, B., (1975). How to Control to Reduce Inventory. Englewood Cliffs, NJ: Prentice-Hall.

Simchi-Levi, D., \& Zhao, Y., (2005). Safety stock positioning in supply chains with stochastic lead times. Manufacturing \& Service Operations Management, 7(June 2015), 295-318. 